\title{
Chemical Composition and Cytotoxic Activity of Chenopodium ambrosioides L. Essential Oil from Togo
}

\author{
Koffi Koba $^{\mathrm{a}^{*}}$, Guyon Catherine ${ }^{\mathrm{b}}$, Christine Raynaud ${ }^{\mathrm{c}}$, Jean-Pierre Chaumont ${ }^{\mathrm{b}}$, \\ Komla Sanda $^{\mathrm{a}}$ and Nicod Laurence ${ }^{\mathrm{b}}$
}

${ }^{a}$ Unité de Recherche sur les Agroressources et la Santé Environnementale, Ecole Supérieure d'Agronomie, Université de Lomé, BP. 20131, Lomé Togo. ${ }^{b}$ Equipe des Sciences Séparatives et Biopharmaceutiques (2SB) EA

479 Faculté de Médecine et de Pharmacie, Université de Franche-Comté, Place Saint-Jacques, 25030, Besançon, France. 'Laboratoire de Chimie Agro-Industrielle, UMR 1010, INRA/INP-ENSIACET, 118, route de Narbonne, 31077 Toulouse cedex, France.

\begin{abstract}
The leaf essential oil of Chromolaena odorata L. (Chenopodiaceae) from Togo were steam-distilled, analyzed by GC and GC-MS for chemical composition and investigated in vitro for its potential cytotoxic activity on human epidermic cell line HaCat. The chemical composition showed that the main constituents of essential oil sample were respectively ascaridole (51.12 \%), p-cymene (19.88 \%), neral (8.70\%) and geraniol (7.55\%). The in vitro cytotoxicity bioassays on human cell line HaCaT revealed moderate toxicity level of C. ambrosioides essential oil $\mathrm{IC}_{50}$ with $700 \mu \mathrm{L} \cdot \mathrm{mL}^{-1}$. Pure commercial neral standard showed high toxicity with $\mathrm{IC}_{50}$ value of $100 \mu \mathrm{L}$. $\mathrm{mL}^{-1}$ ). Conversely, pure ascaridole p-cymene and geraniol standards appeared almost non-toxic $\left(\mathrm{IC}_{50}>1000 \mu \mathrm{L} \cdot \mathrm{mL}^{-1}\right)$, proving the major role played by neral in the overall toxicity showed by the C. ambrosiodes oil sample tested in this work.
\end{abstract}

Keywords: Chenopodium ambrosioides, Essential oil, Ascaridole, p-cymene, HaCaT cell line, Cytotoxicity.

\section{Introduction}

The genus Chenopodium of the family Chenopodiaceae is composed by 120 species, 45 of which are known to be distributed all over the world, which are reported to posses many medicinal properties (Guyot, 1992). The species Chenopodium ambrosioides L. commonly called Mexican tea is an herb that has been used for centuries to expel parasitic worms from the body (Chevallier, 1996). Especially $C$. ambrosioides is widely used in popular medicine as a vermifuge, emmenagogue and abortifacient (Comway \& Slocumb, 1979). C. ambrosioides herb is also used both as anthelmintic, antiparasitic (Kliks, 1985; Giove Nakazawa, 1996; Quinlan et al., 2002), antiplasmodial (Pollack et al., 1990) and as condiment in small amounts that impart an acceptable flavour (Anonymous, 1950). An infusion can be used as a digestive remedy, being taken to settle a wide range of problems such colic and stomach pains (Chevallier, 1996). Externally, it has been used as a wash for haemorrhoids, as a poultice to detoxify snake bites and other poisons and is thought to have wound-healing properties (Chevallier, 1996). The plant is also used as a fumigant against mosquitoes (Gillij et al., 2008) and is also added to fertilizers to inhibit insect larvae (Bown, 1995; Clovd and Chiasson, 2007).

\footnotetext{
* Corresponding author: E-mail: danielkkoba@yahoo.fr
}

The plant can also cause dermatitis or other allergic reactions (Foster and Duke, 1995). C. ambrosioides essential oils chemotypes had insecticidal and acaricidal properties (Chiasson et al., 2004).

Recently, particular attention has been given by researchers to the use of essential oils from tropical origin as active ingredients in various pharmaceutical formulations against some skin troubles (Orafidiya et al., 2001; Orafidiya et al., 2002) like human mycosis. Indeed, naturally occurring molecules of essential oils are more and more considered as valid additives to conventional antibiotherapies (Chaumont et al., 2001; Koba, 2003).

Intensive work is done to record the possible cytotoxic potential of plants essential oils on human cell lines (Dubey et al., 1997; Foray et al., 1999; Hayes et al., 1999; Koba et al., 2007) and their other biological applications all over the world but according to our knowledge no any works has been reported in the relevant work regarding C. ambrosioides oil chemotypes in Togo.

The aim of the present research was to investigate about the chemical composition and the in vitro cytotoxic potential of 
C. ambrosioides L. essential oil from Togo. According to the literature report the assumption is made that $C$. ambrosioides can caused dermatitis or other allergic reactions (Foster and Duke, 1990) when in contact with skin and may be toxic to the human epidermic cell line HaCaT.

\section{Materials and Methods}

\section{Plant material sampling and volatile oils isolation}

Leaves and inflorescences of C. ambrosioides L. used in this work were harvested from plants at full flowering stage in the experimental field of the "Unité de Recherche sur les Agroressources et la Santé Environnementale" at the "Université de Lomé" on October 2005.

Plant specimen was identified by Pr. Akpagana, "Departement de Botanique, Faculté des Sciences" at the Université de Lomé (Togo), where Voucher specimen was deposited in the Herbarium.

A sample (50 g) of air-dried plant material was extracted by the hydro-distillation technique during 2 hours in a modified Clevenger-type glass apparatus (Craveiro et al., 1976). The extracted crude essential oil was stored in hermetically sealed dark glass flasks with rubber lids, covered with aluminum foil to protect the contents from light and kept under refrigeration at $4^{\mathrm{O}} \mathrm{C}$ until use without any prior purification.

\section{Essential oil analyses}

\section{Gas chromatography analysis}

Gas chromatographic analysis was carried out on a Varian 3300 type gas chromatograph equipped with FID detector. An apolar capillary column DB-5 (30 m x 0.25 mm i.d.; film thickness $0.25 \mu \mathrm{m}$ ) and on a polar column Supelcowax 10 with the same characteristics as above mentioned were used. DB-5 column operating conditions were as follows: from 50 ${ }^{\mathrm{O}} \mathrm{C}(5 \mathrm{~min}), 50^{\mathrm{O}} \mathrm{C}$ to $250^{\circ} \mathrm{C}$ at the rate of $2{ }^{\mathrm{O}} \mathrm{C} / \mathrm{min}$ and Supelcowax 10 from $50^{\circ} \mathrm{C}(5 \mathrm{~min}), 50{ }^{\circ} \mathrm{C}$ to $200^{\circ} \mathrm{C}$ at $2{ }^{\mathrm{O}} \mathrm{C} / \mathrm{min}$. The injector and detector temperatures were respectively $250^{\circ} \mathrm{C}$ and $300^{\circ} \mathrm{C}$. The carrier gas was helium at a flow rate of $1.50 \mathrm{ml} / \mathrm{min}$. Samples $(0.2 \mu \mathrm{l})$ of non diluted essential oil were injected manually.

\section{Gas chromatography-Mass spectrometry analysis}

The GC/MS analysis was carried out on a Hewlett Packard 5890 SERIES II chromatograph, coupled with a mass spectrometer of the Hewlett Packard 5971 SERIES type operating in the EI mode at $70 \mathrm{eV}$. The capillary column type was $\mathrm{DB}_{5}$-MS (30 m x $0.25 \mathrm{~mm}$ i.d.; film thickness $0.25 \mu \mathrm{m}$ ). The amount of sample injected and GC/MS parameters were the same as above.

\section{Identification of components}

The components of oil sample were identified by their retention time, retention indices relative to $\mathrm{C}_{5}-\mathrm{C}_{18}$ n-alkanes, computer matching with Willet 275.L library and as well as by comparison of their mass spectra with the authentic samples or with data already available in the literature (Kondjoyan \& Berdagué, 1996; Adams, 2001).

The percentage of composition of the identified compounds was computed from the GC peak area without any correction factor and was calculated relatively.

\section{Biological assay}

\section{Materials}

Dubelcco's Modified Eagle's Minimum Essential Medium (DMEM), foetal calf serum (FCS), trypsin (0.25\%) were from D. Dutscher (Brumath, France). 3-(4,5-dimethylthiazol-2-yl)-2,5-diphenyltetrazolium bromide (MTT), dimethylsulfoxide (DMSO), polyoxyethylene 20 sorbitan monoleate (Tween $80^{\circledR}$ ), N-(2-hydroxyethyl) piperazine-N'(2-ethanesulfonic acid) (HEPES), were purchased from Sigma-Aldrich (Saint Quentin Fallavier, France). Phosphate Buffered Saline (PBS) without calcium and magnesium was purchased from VWR International (Cergy-Pontoise, France).

Pure ascaridol, p-cymene, geraniol and neral from commercial origin were purchased from Sigma Chemical Co. St. Louis USA.

\section{HaCaT Cell culture}

HaCaT, an immortalized human keratinocyte line was a generous gift from Nathalie Gault (Commissariat à l'Énergie Atomique, Bruyère Le Châtel, France) (Boukamp et al., 1988 ; Gault et al., 2002). Cells were routinely grown in Costar plastic flasks in monolayer cultures in DMEM medium supplemented with $10 \%$ (V/V) FCS, and 5 M of HEPES $+80 \mathrm{mg} . \mathrm{L}^{-1}$ of gentamicine. They were grown in a humidified atmosphere of $5 \% \mathrm{CO}_{2}$ in air. The medium was routinely renewed 2, 4 and 6 days after passage and when confluence was reached; cells were trypsinized and split for subcultures (seeding density 3500 cells/ $\mathrm{cm}^{2}$ in a $75 \mathrm{~cm}^{2}$ flask) or used for cytotoxicity assays. Cells were used for experiments within 10 passages to ensure cell line stability. All the experiments were carried out at $37^{\circ} \mathrm{C}$. 


\section{Cytotoxicity assay}

\section{Treatment of cell cultures with tested essential oils and their commercial components}

HaCaT cells were seeded at a density of 6 x 104 cells per well in $100 \mu \mathrm{L}$ culture medium containing 10 \% FCS on 96 multiwell culture plates and incubated overnight for adherence. The next day, the medium was removed and cells were incubated in FCS-free medium containing increasing concentrations (from 50 to $1000 \mu \mathrm{L} . \mathrm{mL}^{-1}$ ) of C. ambrosioides essential oils or their major components from commercial origin (Pure ascaridole, p-cymene, geraniol and neral ) solubilised in $1 / 10$ Tween $80^{\circledR}$ in culture medium (with $<0.1 \%$ Tween $80 \AA$ an ethanol vehicle). Each experiment was carried out in triplicate.

\section{Determination of cell viability}

After the exposure period, the reaction medium was removed and the adhering cells washed with PBS. One hundred microliter of MTT solution ( 0.5 g. $\mathrm{L}^{-1}$ in medium) was added to each culture well. After incubating for 4 hours at $37^{\mathrm{O}} \mathrm{C}$, the MTT reaction medium was removed and formazan-blue was solubilised in $100 \mu \mathrm{L}$ DMSO. This assay is based on the reduction of yellow tetrazolium salt MTT by the mitochondrial succinate deshydrogenase to form an insoluble formazan-blue product. Only viable cells with active mitochondria reduce significant amounts of MTT (Mosmann, 1983) and formazan-blue formation absorbance was recorded in an $\mathrm{EL}_{\mathrm{X} 800} \mathrm{UV}$, Universal Microplate Reader spectrophotometer at $570 \mathrm{~nm}$. Values of absorbance were converted into percentage of residual viability. Usually, inhibition concentration $50 \%\left(\mathrm{IC}_{50}\right)$ is chosen as the best biological marker of cytotoxicity.

The inhibition (I) of the essential oils dilutions in percent was calculated as follows:

$$
\mathrm{I}=\left(\frac{A_{o}-A_{1}}{A_{o}}\right) \times 100
$$

Ao is the absorbance of the control reaction (containing all reagents except the tested compounds), and $A_{1}$ the absorbance with the tested substances (crude essential oils or pure commercial component).

The $\mathrm{IC}_{50}$ (inhibition concentration $50 \%$ ) value represented the concentration of the tested compounds or essential oils that caused $50 \%$ cells inhibition.

\section{Results and Discussion}

\section{Chemical composition of tested essential oils}

The colourless essential oil of C. ambrosioides was obtained in yields of $0.8 \%$ based on dried extracted material. The chemical composition of the studied oil samples are listed in Table I. Eleven compounds were identified in the C. ambrosioides oil sample representing $99.03 \%$ of the detected compounds that included ascaridole (51.12\%), p-cymene (19.88 $\%)$, neral (8.70 \%) and geraniol (7.55\%) as major components. Other notable components identified in this oil were $\alpha$-terpinene (6.35 \%), carvacrol (2.10\%). This oil consisted of five monoterpene hydrocarbons (28.94\%) and six oxygenated monoterpenes (70.09\%).

Table I. Chemical composition of Chenopodium ambroisioides L. essential oil from Togo

\begin{tabular}{|c|c|c|c|}
\hline \multirow[t]{2}{*}{ Compounds } & \multicolumn{2}{|c|}{ Retention indices } & \multirow{2}{*}{$\begin{array}{c}\text { Peak area } \\
{[\%]^{\mathrm{i}}}\end{array}$} \\
\hline & $\mathrm{RI}^{\mathrm{ii}}$ & $\mathrm{RI}^{\mathrm{iii}}$ & \\
\hline Monterpene hydrocarbons & & & 28.94 \\
\hline$\alpha$-terpinene & 1023 & 1189 & 6.35 \\
\hline p-cymene & 1033 & 1273 & 19.88 \\
\hline trans- $\beta$-ocimene & 1069 & 1250 & 0.51 \\
\hline$\gamma$-terpinene & 1041 & 1252 & 1.52 \\
\hline terpinolene & 1095 & 1283 & 0.68 \\
\hline Oxygenated monterpenes & & & 70.41 \\
\hline p-mentha, 1, 2, 8 triene & 1109 & & 0.32 \\
\hline ascaridol & 1237 & & 51.12 \\
\hline neral & 1238 & & 8.70 \\
\hline geraniol & 1253 & & 7.55 \\
\hline carvacrol & 1299 & 2229 & 2.10 \\
\hline isoascaridol & 1302 & & 0.62 \\
\hline Total identified & & & 99.35 \\
\hline
\end{tabular}

${ }^{\text {i}}$ Peak area percentage is based on apolar DB-5 column, and values represent average of three determinations

${ }^{\text {ii }}$ Retention indexon apolar DB-5 column

${ }^{\text {iii }}$ Retention index on polar Supelcowax 10 column

This composition was near to previous reports on C. ambrosioides oil from Madagascar (Cavalli et al., 2004), but differed from those described in Brazil by Jardim et al. in 2008 with (Z) ascaridole (61.4\%), (E) ascaridole (18.6 \%), pcymene (2.0\%) as major components and in India by Gupta et al. in 2002 with $\alpha$-terpinene (63.6 \%) p-cymene (19.5\%) and ascaridole (6.2\%) as major components of the oil. 


\section{Cytotoxicity of tested essential oil samples}

The percentage of HaCaT cell viability and the $\mathrm{IC}_{50}$ values recorded for tested essential oil sample and its four major constituents from commercial origin are shown in Table II.
Tested essential oil induced significantly increased cell cytotoxicity, from the lower to higher concentrations ranging from 50 to $1000 \mu \mathrm{L} \cdot \mathrm{mL}^{-1}$. Two types of profiles were observed: (i) tested C. ambrosioides oil and pure neral, standards showed cytotoxicity towards HaCaT with following

Table II. In vitro viability of human skin cell line HaCat exposed to C. ambroisioides essential oils and their major constituents

\begin{tabular}{|c|c|c|c|c|c|}
\hline \multirow{3}{*}{$\begin{array}{l}\text { Concentrations } \\
\mu \mathrm{L} / \mathrm{mL}\end{array}$} & \multicolumn{5}{|c|}{ Cell viability (\%) } \\
\hline & \multicolumn{2}{|l|}{ Essential oil } & \multicolumn{3}{|c|}{ Major constituents of essential oils } \\
\hline & C. ambroisioides & Ascaridole & p-cymene & Geraniol & Neral \\
\hline Control (0) & $100 \pm 00$ & $100 \pm 00$ & $100 \pm 00$ & $100 \pm 00$ & $100 \pm 00$ \\
\hline 50 & $96 \pm 1.73$ & $135.66 \pm 1.15$ & $126 \pm 1.15$ & $98.66 \pm 0.57$ & $85.66 \pm 1.15$ \\
\hline 100 & $93 \pm 1.00$ & $131 \pm 1$ & $120 \pm 1$ & $110.66 \pm 1.15$ & $50.66 \pm 0.57$ \\
\hline 150 & $90.66 \pm 0.57$ & $128 \pm 00$ & $115 \pm 00$ & $114.33 \pm 1.15$ & $47.33 \pm 0.57$ \\
\hline 200 & $89 \pm 1$ & $123.66 \pm 1.15$ & $110 \pm 1.15$ & $116 \pm 1.73$ & $44.66 \pm 0.57$ \\
\hline 250 & $85.33 \pm 0.57$ & $120.33 \pm 0.57$ & $108 \pm 0.57$ & $119.33 \pm 1.15$ & $40.33 \pm 0.57$ \\
\hline 300 & $83.66 \pm 0.57$ & $118.33 \pm 2.08$ & $105 \pm 1.52$ & $125.33 \pm 0.57$ & $38.66 \pm 0.57$ \\
\hline 350 & $80.33 \pm 0.57$ & $115.33 \pm 0.57$ & $103 \pm 0.57$ & $129.33 \pm 1.15$ & $30.33 \pm 0.57$ \\
\hline 400 & $75.66 \pm 0.57$ & $110 \pm 1.73$ & $102 \pm 1.52$ & $134.33 \pm 0.57$ & $25.66 \pm 0.57$ \\
\hline 450 & $71.00 \pm 1.00$ & $108 \pm 1$ & $98.66 \pm 0.57$ & $137.66 \pm 0.57$ & $21.00 \pm 1$ \\
\hline 500 & $69.33 \pm 1.15$ & $104.66 \pm 0.57$ & $95 \pm 0.57$ & $140.33 \pm 0.57$ & $19.33 \pm 1.15$ \\
\hline 600 & $56.66 \pm 1.52$ & $93.66 \pm 1.52$ & $93.33 \pm 1$ & $142.66 \pm 0.57$ & $16.66 \pm 1.52$ \\
\hline 700 & $50.66 \pm 1.52$ & $93.66 \pm 1.15$ & $92.66 \pm 0.57$ & $144.66 \pm 0.57$ & $11.66 \pm 1.52$ \\
\hline 800 & $45.66 \pm 1.15$ & $92.33 \pm 0.57$ & $93.33 \pm 0.57$ & $147.33 \pm 1.15$ & $10.66 \pm 1.15$ \\
\hline 900 & $40.66 \pm 0.57$ & $90.66 \pm 1.15$ & $92.66 \pm 1.52$ & $150.33 \pm 0.57$ & $5.66 \pm 0.57$ \\
\hline 1000 & $30.66 \pm 0.57$ & $90.33 \pm 1.15$ & $93.66 \pm 1.15$ & $154.33 \pm 1.15$ & $4.66 \pm 0.57$ \\
\hline
\end{tabular}

Viability expressed as mean \pm S.D, $\mathrm{n}=3$.

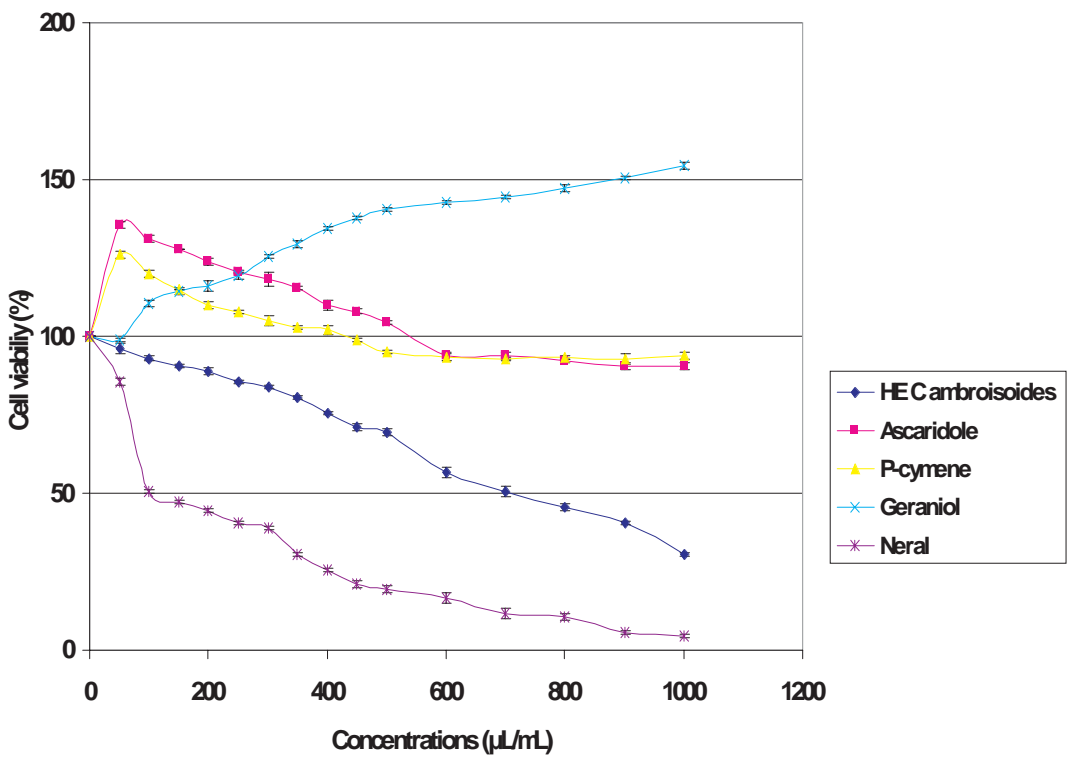

Fig. 1. In vitro viability of human cell line HaCat exposed to C. ambroisiodes essential oil and their major coumpounds 
respective $\mathrm{IC}_{50}$ values $\left(100,700 \mu \mathrm{L} . \mathrm{mL}^{-1}\right)$ shown in Table II; (ii) pure ascaridole, p-cymene et geraniol standard did not show any cytotoxicity up to $1000 \mu \mathrm{L}$. $\mathrm{mL}^{-1}$ with respectively cell viability 90.33, 93.66 and $154 \%$.

These experimental results showed that, of the four major constituents of tested essential oil, neral, was the most toxic for HaCaT cell line. Consequently the cytotoxic effect of the essential oils of $C$. ambrosioides found in this investigation was undoubtedly due to neral. Our previous works on in vitro cytotoxicity of $C$. citratus and $C$. nardus essential oils from Togo on cell line HaCaT assumed what we experimentally established to a large extent in this investigation, and provide numerical data on the toxicity of the essential oils rich in citral on human skin cell line (Koba et al., 2009). Apart from its inherent toxicity, some authors have reported that citral, a mixture of both geranial and neral stereoisomers, had a significant ability to suppress oxidative stress possibly through induction of the endogenous antioxidant glutathione system, providing a new insight into skin cancer (Nakamura et al., 2003). Besides, ascaridole, p-cymene and geraniol, as some of the main constituents of the C. ambrosioides sample tested in this work, did not show any cytotoxicity. But they could probably expressed their potential as cytoprotectors or as antioxidants in subsequent oxidative stress assays.

\section{Conclusion}

In this paper, the investigation of chemical composition of the essential oil of $C$. ambrosioides along with the evaluation of its cytotoxic activity on human cell line HaCaT is quite a typical applied research. The present study has shown a potential cytotoxic activity of $C$. ambrosioides essential oil on human cell line HaCaT. But this essential oil of C. ambrosioides, with a percentage composition identical to our tested oil chemotype in this investigation, when used in appropriate doses, could be quite suitable as active components in pharmaceutical formulations for skin treatment and its damages repairing. Further required clinical investigations will include other important studies like contact allergy tests, which might be linked to the use of essential oils as active ingredients.

\section{Acknowledgment}

Authors wish to thank Université de Lomé and AUF (Agence Universitaire de la Francophonie) for financial support of this study.

\section{References}

Adams R. P. (2001). Identification of essential oil components by gas chromatography/quadrupole mass spectrodcopoy. Allured Publishing Corporation, Carol Stream, Ilinois. 9-24.

Anonymous. (1950). The wealth of India, Vol.2 Raw material, CSIR New Dehli, India. p. 127-128.

Boukamp P., Petrussevska R. T., Breitkreutz D., Hornung J., Markham A. and Fusenig N. E. (1988). Normal keratinization in spontaneously immortalized aneuploid human keratinocyte cell line. J. Cell Biol. 106: 761-771.

Bown. D. (1995). Encyclopaedia of Herbs and their Uses. Dorling Kindersley, London. ISBN 0-7513-020-31.

Cavalli J. F., Tomi F., Bernardini A. F. and Casanova J. (2004). Combined analysis of the essential oil Chenopodium ambrosioides by GC, GC-MS and 13CNMR spectroscopy: quantitative determination of ascaridole, a heat-sensitive compound. Phytochem Anal. 15(5):275-279.

Chaumont J. P., Mandin D., Sanda K., Koba K. and de Souza C.A. (2001). Activités antimicrobiennes de cinq huiles essentielles de Lamiacées togolaises vis-à-vis de de germes représentatifs de la microflore cutanée. Acta. Bot. Gallica. 148(2): 93-101.

Chevallier A. (1996). The Encyclopedia of Medicinal Plants Dorling Kindersley. London, ISBN9-780751-303148

Chiasson H., Vincent C. and Bostanian N. J. (2004). Insecticidal properties of a Chenopodium-based botanical. J Econ Entomol. 97(4): 1378-1383.

Chiasson H., Bostanian N. J. and Vincent C. (2004). Acaricidal properties of a Chenopodium-based botanical. J Econ Entomol. 97(4): 1373-1377.

Comway G. A. and Slocumb J. C. (1979). Plants used as abortifacients and emmenagogues by Spanish New mexicans. J Ethnopharmacol 1(3): 241-261.

Clovd R. A., Chiasson H. (2007). Activity of essential oil derived from Chenopodium ambrosioides on green house insect pests. J Econ Entomol. 100(2): 459-466.

Craveiro A. A., Matos F. J. and Alencar J. W. (1976). A simple and inexpensive steam generator for essential oils extraction. J. Chem. Ed. 53: 652.

Dubey N. K., Kishore N., Varma J. and Lee S. Y. (1997). Cytotoxicity of the essential oils of Cymbopogon citratus and Ocimum gratissimum. Indian J. Pharm Sci. 59(5): 263-264. 
Dubey N. K., Tekeya K. and Itokawa H. (1997). Citral: a cyttotoxic principle isolated from the essential oil of Cymbopogon citratus against P388 leukemia cells. Curent Sciences. 73(1): 22-24.

Foster. S. and Duke. J. A. (1990). A Field Guide to Medicinal Plants. Eastern and Central N. America. Houghton Mifflin Co. ISBN 0395467225.

Foray L., Bertrand C., Pinguet F., Soulier M., Astre C., Marion C., Pélissier Y. and Bessière J. M. (1999). In vitro cytotoxic activity of three essential oils from Salvia Species. J Essent Oil Res. 1: 522-526.

Gault N., Vozenin-Brotons M. C., Calenda A., Lefaix J. L., and Martin M.T. (2002). Promoter sequences involved in transforming growth factor beta 1 gene induction in HaCaT keratinocytes after gamma irradiation. Radiat Res. 157: 249-255.

Gillij Y. G., Gleiser R. M. and Zygadlo J. A. (2007). Mosquito repellent activity of essential oils of aromatic plants growing in Argentina. Bioresour Technol. 99 (7): 2507-2515.

Giove Nakazawa R. A. (1996). Traditional medicine in treatment of enteroparasitosis. Rev Gastroenterol Peru. 16(3):197-202.

Gupta D. Charles R., Mehta V.K., Garg S. N., and Kumar S. (2002). Chemical examination of the essential oil of Chenopodium ambrosioides L. from the Southern Hills of India. J Essent Oil Res. 14 : 93-94

Hayes A. J., Leach D. N. and Markham J. L. (1999). Markovic B. In vitro cytotoxicity of Australian Tea Tree Oil using human cell lines. J Essent Oil Res. 9: 575-582.

Jardim C. M., Jham G. N., Dhingra O. D. and Freire M.M. (2008). Composition and antifungal activity of the essential oil of the Brezilian Chenopodium ambrosioides L. J Chem Ecol. 34(9): 1213-1218.

Koba K. (2003). Activités antimicrobiennes des huiles essentielles de quatreLamiacées de la flore Togolaise sur des germes de la microflore cutanée : Application à la formulation d'émulsions à usage topique. Thèse de doctorat unique, Faculté des Sciences. Université de Lomé. no. 080.

Koba K., Sanda K., Guyon C., Raynaud C., Millet J., Chaumont J. P. and Nicod L. (2007). Chemical composition and in vitro cytotoxic activity of essential oils from two tropical Lamiaceae: Aeollanthus pubescens Benth. and Ocimum gratissimum L. J. Essent. Oil
Bear. Plants. 10: 60-69.

Koba K., Sanda K., Guyon C., Raynaud C., Chaumont J. P. and Nicod L. (2009). In vitro cytotoxic activity of Cymbopogon citratus L. and Cymbopogon nardus L. essential oils from Togo. Bangladesh J Pharmacol. 4: 29-34.

Kondjoyan N., and Berdagué J. L. (1996). A compilation of relative retention indices for the analysis of aromatic compounds: Ed. Laboratoire Flaveur, INRA de Theix, France. p 234.

Kliks M. M. (1985). Studies on traditional herbal anthermintic Chenopodium ambrosioides L.: ethnopharmacological evaluation and clinical trials. Soc Sci Med. 21(8):879-886.

Michel G. (1992). Systématique des Angiospermes (Référence à la flore du Togo). Edition Les Presses de l'EDITOGO, Lomé Togo. p 47-49.

Mosmann T. (2003). Rapid colorimetric assay for cellular growth and survival: application to proliferation and cytotoxic assays. J Immunol Meth. 65: 55-63.

Nakamura Y., Miyamoto M., Murakami A., Ohigashi H., Osawa T. and Uchida K. (2003). A phase II detoxification enzyme inducer from lemongrass: identification of citral and involvement of electrophilic reaction in the enzyme induction. Biochem. Biophys. Res. Commun. 302(3):593-600.

Orafidiya L. O., Oyedele O. A., Shittu O. A. and Elujoba A. A. (2001). The formulation of an effective topical antibacterial product containing Ocimum gratissimum leaf essential oil. Int. J. of Pharm. 224: 177-183.

Orafidiya L. O., Agbani E. O., Oyedele O. A., Babalola O. O. and Onayemi O. (2002). Preliminary clinical tests on topical preparations of Ocimum gratissimum Linn leaf essential oil for the treatment of acne vulgaris. Clin Drug Invest. 22(5): 313-319.

Pollack Y., Segal R. and Golenser J. (1990). The effect of ascaridole on the development of Plasmodium falsiparum. Parasitol Res. 76(7): 570-572.

Quinlan M. B., Quinlan R. J. and Nolan J. M. (2002). Ethnophysiology and herbal treatments of intestinal worms in Dominica, West Indies. J Ethnopharmacol. 80(1): 75-83.

Received : August 31, 2008;

Accepted : July 24, 2009 